\title{
Type of Event ICSR Terminology
}

National Cancer Institute

\section{Source}

National Cancer Institute. Type of Event ICSR Terminology. NCI Thesaurus. Code C54580.

Terminology used in Individual Case Safety Reports for identifying the type of event (adverse event or product problem), section B1 of FDA MedWatch Form. 